\title{
The Implementation Of Entrepreneurship Education and Production Unit In Vocational High Schools
}

\author{
Marniati, Mein Kharnolis \\ Departement of Home Economics \\ Universitas Negeri Surabaya \\ Surabaya Indonesia \\ marniati@unesa.ac.id
}

\author{
Agus Hery Supadmi Irianti \\ Departement of Industrial Technology \\ Universitas Negeri Malang \\ Malang Indonesia \\ agushery-um52@yahoo.com
}

\begin{abstract}
Production unit in vocational high schools is a place to train students with entrepreneurship practice. Teachers utilize this unit to help students developing competence in production lesson. Research uses quantitative approach. Subject includes 40 teachers of cloth-making lesson in vocational high schools of East Java. Data collection method is documentation and questionnaire with Likert Scale entailing five answer alternatives. Data analysis technique involves T-Test and Explanatory Factor Analysis. Some findings are obtained: (1) Practice-based activity at production unit in vocational high schools is more effective than same activity in Modeste Industry; (2) Practice-based activity at production unit in vocational high schools is very highly effective because teachers are highly oriented toward practice, more creative in preparing learning activity, and more explicit in guiding students during practice lesson; (3) Schools, teachers, and school staffs gain benefits from effective activity at production unit; and (4) Entrepreneurship education improves teachers' capability in designing production learning activity. Research is aimed to measure the effectiveness of the implementation of entrepreneurship education, to estimate teachers' effectiveness in providing practice-based guidance at production unit, and to understand the benefits of practice-based activity at production unit that can be obtained by teachers, students, and school staffs.
\end{abstract}

Keywords-production unit; entrepreneurship education; vocational high schools

\section{INTRODUCTION}

Practice-based activity at production unit can be used as a learning-by-doing structure that would benefit the students of Vocational High Schools. It is true that vocational high school is a place to develop a reliable human resource and a skillful workforce. Mukhadis said that Vocational Education would be a structure to facilitate the development of skills among individuals or groups which then provide them opportunity to be job creator, competitive job seeker, and high degree pursuer (one with high capacity of diligence) in global context. [1]

The youths graduate from their school without the needed skills or competencies that would enable them functioning in the society. According to J.F. Maigida \& T.M. Saba, this issue has reached alarming proportion. This is because the youth represents a tremendous potentials for the development of human capital which the society cannot afford to neglect. Young people's situation and future prospects are vital concerns to take into account.[2]

Vocational education involves a curriculum that focuses on relevant aspects such as psychomotor, affective and cognitive. The success measure of this curriculum is based on its sensitivity to the development of employment world. Learning about a business at school-based production unit would be meaningful, especially when this unit is managed professionally and designed to help students, teachers and school staffs to understand industrial value standards and to create the mindset and behavior of business, which allow them to be educated with entrepreneurship. As said by Mon'im AlSaaideh \& Atif Bin Tareef, this success may only be achieved through some actions, such as: the status of teachers must be subjected to standards; the design of program that fits to recent conditions shall be investigated; administrative and financial facilities must be checked to ensure its feasibility to implement entrepreneurship education program at school. Moreover, it is also important to measure the effect of this program on teacher performance, teacher's attitude on work, and teacher's work satisfaction. Perspectives of other stakeholders in vocational high schools about entrepreneurship education must also be considered.[3]

However, the fact shows that the implementation of entrepreneurship values at production lesson in vocational high school is still less. Students are only compelled to do business practice or production experiment as the part of curriculum disregarding how important are these entrepreneurship values to be understood if students are also required to market the outputs of their practice/production. This understanding would at least create attitude and behavior toward entrepreneurship among students.[4] By taking into account this issue, an empirical review is then conducted on production lesson teachers at Skill Program of Cloth-Making in Vocational High Schools of East Java. This review concerns with the role of entrepreneurship education and production unit in vocational high schools. The role of both features is understood from the effectiveness of teachers in delivering entrepreneurship lesson and also from the 
utilization of production unit. Entrepreneurship education is focused on creating into students of some important characters such as: discipline, responsibility, initiative, mastery of science and technology, and competence in cloth-making. Production unit is emphasized on benefits derived from individual sewing order (Custom-Made Atelier). These benefits include income, welfare, equipment and also knowledge and skill.

Sharmila Sandirasegarane, Staci Sutermaster, Alyssa Gill, Jennifer Volz, \& Khanjan Mehta explicitly asserted that vocational institutions cannot escape from critics, and one is that they focus more on training the needed skills without addressing related business systems. Thus, students may not understand the business strategies related to their field, which it may stiffle job readiness and entrepreneurial potential.[5] To counter this, vocational education must apply entrepreneurship education approach which is more integrated and contextdriven. Benefits and disadvantages of various types of vocational and entrepreneurial programs are evaluated to determine how their strengths could be leveraged. This position is consistent with the result of study by Elena Ruskovaara \& Timo Pihkala on entrepreneurship training for teachers, where they found that entrepreneurship training received by teachers is the key factor determining teachers' degree of understanding on entrepreneurship education.[6] The integrated training on vocation and entrepreneurship would address the market demand for context-specific workforce through providing both practical and transferrable skills.

\section{METHOD}

Taking account the approach, then research type is cross-sectional because at certain time interval, or in simultaneous way, the authors observes and makes a transcription of responses given by respondents (teachers of Vocational High School) when they answer questions related with research variables. Research sample involves 40 teachers who are determined with proportional random sampling. Data collection method includes documentation and questionnaire with Likert Scale consisting of five answer alternatives. Data analysis technique involves T-Test and Explanatory Factor Analysis.

\section{RESULT AND DISCUSSION}

Result of descriptive analysis has proved that the marketing of products from production unit has given some benefits. It increases revenue and income of school and school staffs. It also helps the school to complete equipment and also facilitate the activity of production lesson at class and production practice at production unit. Some proportions of earnings from the marketing can be set aside for giving incentives for teachers who serve the study program of clothmaking in vocational high schools. Indeed, earnings from marketing would improve the welfare of students, teachers, and school staffs.
It is set in a proposition that the implementation of entrepreneurship education at study program of coth-making in vocational high schools would increase the discipline of students in learning activity. This proposition is supported by 8 respondents of teacher $(20 \%)$ who perceive the relationship as effective, while 32 respondents $(80 \%)$ consider it as very effective. As noted by Ngozi Nwabufo \& Joshua Mamman, effective learning in entrepreneurship education can increase the discipline of students in following the learning activity. Entrepreneurship education involves teaching and learning of the needed skills and knowledge that equip one to become self-reliant, or to be effective and successful initiator, manager, innovator and risk bearer of business enterprise, and they do this in effective and successful ways. [7]

It is also proposed that practice-based activity at Production Unit would help creating leadership and discipline postures into students during cloth-making practice. The proposition has been supported by 10 respondents of teacher $(25 \%)$ who consider the activity as very effective, whereas 30 respondents $(75 \%)$ regard it effective. It agrees with the position of Dianne H.B. Welsha, William L. Tullarb, \& Hamid Nematic who declared that to educate students to become entrepreneur, the change is the cornerstone before students go to a life reality.[8]

Result of research indicates that practice-based activity at school-based production unit can develop creativity and initiative of students to provide premium service to consumers who visit cloth workshop. This statement is supported by 12 respondents of teacher $(30 \%)$ who report that the role played by production unit is very effective, while 28 respondents (70\%) perceive it as effective. The implementation of entrepreneurship education at Study program of cloth-making in vocational high schools of East Java has very high degree of effectiveness. It is said so because teachers start to be highly oriented toward practice, be more creative in preparing learning activity, and be more courageous in working (or making action) of delivering the materials of learning. Adriano Stadler \& Anne M. J. Smith have proved that entrepreneurship education in vocational institution is often associated with specific techniques and teaching methods, including face-toface contact with students and the alignment of knowledge with labour market needs.[9]

Factor analysis has been performed to understand the structure of data of school-based production unit. Result of this analysis has found two factors, respectively capability factor and development factor. Capability factor consists of variables such as revenue, welfare, knowledge and skill, discipline, mastery of learning materials, and responsibility. Each variable has a certain impact on the change of understanding and attitude of students toward entrepreneurship education. Moreover, the positive impact of entrepreneurship education is manifested in the building of entrepreneurship spirit into students, and this spirit is measured in terms of students' willingness for starting-up a new business and a high percentage of students who acknowledge that the entrepreneurial knowledge they have acquired would be useful to them.[10] 
Further proposition has been made, asserting that the marketing of products from school-based production unit (UPS) would help the school to complete equipment and also facilitate the activity conducted by both students and teachers of production lesson at class and production practice at production unit. This proposition is supported by 16 respondents of teacher $(40 \%)$ who perceive this relationship as very effective, whereas 30 respondents $(60 \%)$ consider it as effective. Earnings obtained from marketing UPS products shall help increasing revenue and income of school and school staffs. It aligns with the study of Judowati who found that earnings gained from marketing UPS products would provide greater chance for the school to complete equipment and also to facilitate the activity conducted by both students and teachers of production lesson at class and production practice at Production Unit. [11]

The last proposition is that earnings acquired from marketing UPS products shall improve the welfare of students, teachers and school staffs. This proposition is supported by 16 respondents of teacher (40\%) who consider this relationship as effective, and 24 respondents $(60 \%)$ regard it as very effective. The implementation of entrepreneurship education in vocational high schools takes a reference from national policy for education field. Entrepreneurship education is driven into a direction of building the character and attitude of entrepreneurship among the citizens of vocational high schools. The implementation of entrepreneurship education shall help the school to find more appropriate education strategy that produces education outputs in favorable quality viewed both from academic or non-academic quality. This finding is supported by Jahani \& Hady Efendy who infer that to become successful entrepreneur, main requirement is that students must have spirit and character of entrepreneurs, and both are influenced by skill and competence.[12]

\section{CONCLUSION}

By taking into account the research problems that have been formulated, the objectives of research, and also the results of analysis and its discussion, it can be concluded that the implementation of entrepreneurship education and production unit, as already done by skill program of clothmaking in vocational high schools of east java, have been effective already. The elaboration of this conclusion is given as following.

- Practice-based activity at Atelier (Custom-Made) production unit in vocational high schools is more effective than same activity at Modeste Industry.

- Entrepreneurship education has very high degree of effectiveness because this activity successfully makes teachers to be highly oriented toward practice, be more creative in preparing learning activity, be more courageous in working (or making action) of delivering the materials of learning, and also be more explicit in guiding students during practice lesson
- The effectiveness of activity conducted at Atelier (Custom-Made) production unit in vocational high schools shall give benefits to students, teachers and school staffs, and facilitate them in designing cloth on custom-made.

\section{REFERENCES}

[1] Mukhadis, A, "Evaluasi program pembelajaran bidang teknologi. terminologi, prosedur pengembangan program dan instrument". Malang: Penerbit bayumedia publishing, 2013.

[2] J.F. Maigida T.M. Saba, "Entrepreneurial skills in technical vocational education and training as a strategic approach for achieving youth empowerment in Nigeria". International Journal of Humanities and Social Science Vol. 3, No. 5, Maret 2013.

[3] Mon'im Al-Saaideh and Atif Bin Tareef, "Vocational teacher education research: issues to address and obstacles to face". Journal of Education. Vol 131 No. 4 (Summer 2011): p 715.

[4] Agung Winarno, "Entrepreneurship education in vocational schools: characteristics of teachers, schools and risk implementation of the curriculum 2013 in Indonesia” Journal of Education and Practice Vol.7, No.9, 2016.

[5] Sharmila Sandirasegarane, Staci Sutermaster, Alyssa Gill, Jennifer Volz, and Khanjan Mehta, "Context-driven entrepreneurial education in vocational schools". International Journal for Research in Vocational Education and Training (IJRVET) Vol. 3, Issue 2, August 2016, 106126.

[6] Elena Ruskovaara \& Timo Pihkala, Entrepreneurship education in schools: empirical evidence on the teacher's role. The Journal of Educational Research Volume 108, No. 3, 2015.

[7] Ngozi Nwabufo \& Joshua Mamman, entrepreneurship education: a panacea for curbing graduate unemployment in nigeria. International Journal of Teaching and Education, Vol. III, No. 3 / 2015.

[8] Dianne H.B. Welsha, William L. Tullarb, \& Hamid Nematic, "Entrepreneurship education: Process, method, or both?." journal of innovation \& knowledge, Volume 1, Edisi 3, September-Desember 2016.

[9] Adriano Stadler, Anne M. J. Smith, "Entrepreneurship in vocational education: A case study of the Brazilian context". Sage Journals First Published March 16, 2017.

[10] Chi-Kim Cheung \& Yuk Che Regina Chan, "The introduction of entrepreneurship education to school leavers in a vocational institute". International Journal Of Scientific Research In Education Vol. 4(1), Maret 2011.

[11] Judowati, :Keefektifan pelaksanaan program unit produksi sekolah pada sekolah menengah kejuruan (SMK) di Kota Blitar". Tesis tidak diterbitkan di Malang. Program Pascasarjana UKM. 2010.

[12] Jahani \& Hady Efendy, "Developing of entrepreneurial spirit in the era of asean economic community in vocational high school". International Journal of Learning and Development Vol. 7, No. 3, 2017. 